\title{
Inhibition of Clinical Nosocomial Bacteria by Chlorine Dioxide
}

\author{
Suk-Yul Jung ${ }^{\dagger ; *}$ \\ Department of Biomedical Laboratory Science, Molecular Diagnosis Research Institute, \\ Namseoul University, Cheonan-city, Choongnam 31020, Korea
}

\begin{abstract}
Chlorine dioxide is an effective chemical to inhibit the growth of bacteria and viruses or to disinfect infected areas. In this study, the effects of chlorine dioxide on several bacteria in hospitals were analyzed. Alloiococcus otitis, Kocuria rosea, Leuconostoc mesenteroides spp. and Staphylococcus lentus as gram-positive bacteria and Acinetobacter lwoffii, Aeromonas salmonicida, Brucella melitensis, Oligella ureolytica as gram-negative bacteria were done for the inhibitory analysis. The growth and morphology of the bacteria were analyzed by placing a plastic stick which was called "FarmeTok (medistick/ Puristic)" provided by Purgofarm, co, Ltd. to release $\mathrm{ClO}_{2}(13 \mathrm{ppmv} / \mathrm{hr})$ next to the plate where the bacteria were incubated for 24 hours. Less than 10 bacterial colonies were evaluated as having $99 \%$ inhibitory effect. The initial bacterial culture concentration of $0.5 \mathrm{McFaland}$ turbidity was good for analyzing the chlorine dioxide inhibitory effect. All bacteria could be easily counted post $24 \mathrm{hr}$ co-incubation with $\mathrm{ClO}_{2}$, but $A$. otitis and $A$. lwoffii without $\mathrm{ClO}_{2}$ gas were not countable due to very dispersed colony types which were not affected for result analysis. As shown in this study, the FarmeTok plastic stick, which discharges chlorine dioxide at $13 \mathrm{ppmv} /$ hour, was evaluated to be sufficient to suppress the above bacteria in the hospital. Bacteria existing in the clinic such as this hospital will be used as a data to inhibit the growth of bacteria by using $\mathrm{ClO}_{2}$, and molecular biology analysis using the gene of bacteria will be possible in the future rather than inhibiting the growth of bacteria itself.
\end{abstract}

Key Words: Bacteria, Chlorine dioxide, FarmeTok, Growth

Chlorine dioxide, $\mathrm{ClO}_{2}$, is water-soluble gas of a strong oxidative activity (Moran et al., 1953; Fukayama et al., 1986; Chung et al., 2018), and it is thought to have inhibitory or disinfective effects to bacteria, yeast, molds and viruses (Sy et al., 2005; Morino et al., 2009; Lowe et al., 2013; Kim et al., 2016; Chung et al., 2018). Chlorine dioxide is 10 times more soluble in water than sodium hypochlorite, which is less reactive with organics and used as a disinfectant for food (Jung et al., 2019). $\mathrm{ClO}_{2}$ gas is an effective disinfectant agent with strong oxidization ability and a broad biocidal spectrum (Gómez-López et al., 2009; Wang et al., 2016). Sanekata et al. (2010) reported that chlorine dioxide was treated at a concentrations of 1 to $100 \mathrm{ppm}$ for 15 seconds and it had a powerful antiviral function that inactivated more than $99 \%$ of the virus. In addition, the treatment of chlorine dioxide inhibited the growth of bacteria in crops such as blueberries (Wu and Kim, 2007; Xu et al., 2016) and paprika (Kim and Song, 2017).

In our previous study, microorganisms isolated from nosocomial environment, e.g. Micrococcus luteus, Granulicatella

Received: November 12, 2019 / Revised: December 3, 2019 / Accepted: December 3, 2019

*Professor.

$\dagger$ Corresponding author: Suk-Yul Jung. Department of Biomedical Laboratory Science, Molecular Diagnosis Research Institute, Namseoul University, 91 Daehak-ro, Seonghwan-eup, Seobuk-gu, Cheonan-city, Choongnam 31020, Korea.

Tel: +82-41-580-2723, Fax: +82-41-580-2932, e-mail: syjung@nsu.ac.kr

(C) The Korean Society for Biomedical Laboratory Sciences. All rights reserved.

@ This is an Open Access article distributed under the terms of the Creative Commons Attribution Non-Commercial License (http://creativecommons.org/licenses/by-nc/3.0/) which permits unrestricted non-commercial use, distribution, and reproduction in any medium, provided the original work is properly cited. 
adiacens, Staphylococcus caprae, etc, were inhibited upto $99 \%$ by a plastic stick releasing chlor ine dioxide gas provided by Purgofarm company.

In this study, clinical nosocomially shown bacteria which had little infection case and no report until now were evaluated by the effects of $\mathrm{ClO}_{2}$ gas for inhibition tests. Four gram- positive bacteria and four gram-negative bacteria were applied. Briefly, Alloiococcus otitis, Kocuria rosea, Leuconostoc mesenteroides spp. and Staphylococcus lentus as gram-positive bacteria and Acinetobacter lwoffii, Aeromonas salmonicida, Brucella melitensis, Oligella ureolytica as gram-negative bacteria were done for the inhibition test. Briefly, O. ureolytica is an aerobic gram-negative bacillus in human urinary tracts but $K$. rosea has also been found to cause urinary tract infections in patients with weakened immune systems. L. mesenteroides is associated with slime production. A. otitis is a species of bacteria first isolated from human middle-ear fluid, and S. lentus and A. lwoffii are seen as normal flora of skin. A. salmonicida is an etiological agent for furunculosis which causes sepsis and B. melitensis is a bacterium to cause ovine brucellosis. They were pre- viously isolated from nosocomial environment (Song and Jung, 2017). The isolated bacteria were subcultured into other tryptic soy agar (TSA, MB cell, Korea) plate at $37^{\circ} \mathrm{C}$ and were confirmed by Gram-staining procedures (Lim et al., 1988).

All bacterial strains were stated below: A. otitis, K. rosea, L. mesenteroides spp. and $S$. lentus as gram-positive bacteria and A. lwoffii, A. salmonicida, B. melitensis, O. ureolytica as gram-negative bacteria were done for the inhibition test. Prior to the inhibition test, single bacterial colonies were adjusted to 0.5 of McFaland turbidity, diluted with $0.85 \%$ $\mathrm{NaCl}$ to form approximate $1.5 \times 10^{5}$ to $1.5 \times 10^{8}$ colony forming units (CFU)/mL (Song and Jung, 2017). The bacteria were cultured with TSA medium for the next procedures. Bacteria plates were applied with a plastic stick, namely, "FarmeTok (medistick/Puristic) kindly provided by Purgofarm, co, Ltd. (Hwasung, Gyeonggi-do, Korea)" to produce $\mathrm{ClO}_{2}$ (13 ppmv/hr) (Song and Jung, 2017). In order to observe the growth and culture of bacteria, bacterial plates were placed in a plastic clear chamber $(250 \mathrm{~W} \times 350 \mathrm{D} \times$ $200 \mathrm{H})$ at a $37^{\circ} \mathrm{C}$ incubator and observed for $24 \mathrm{hr}$.

Table 1. The number of bacterial colonies

\begin{tabular}{|c|c|c|c|c|c|}
\hline $\begin{array}{l}\text { Gram } \\
\text { staining }\end{array}$ & Bacteria & Groups & $\begin{array}{l}\text { Initial numbers } \\
(\mathrm{CFU} / \mathrm{mL})\end{array}$ & $\begin{array}{c}\text { Numbers after } 24 \mathrm{hr} \\
(\mathrm{CFU} / \mathrm{mL})\end{array}$ & $\begin{array}{l}\text { Growth inhibition rate } \\
(\%)^{*}\end{array}$ \\
\hline+ & A. otitis & Control & $1.5 \times 10^{8}$ & Uncountable $^{* *}$ & - \\
\hline+ & A. otitis & $\mathrm{ClO}_{2}$ & $1.5 \times 10^{8}$ & 0 & 99.9 \\
\hline+ & K. rosea & Control & $1.5 \times 10^{8}$ & 43 & - \\
\hline+ & K. rosea & $\mathrm{ClO}_{2}$ & $1.5 \times 10^{8}$ & 0 & 99.9 \\
\hline+ & L. mesenteroides spp. & Control & $1.5 \times 10^{6}$ & Uncountable $^{* *}$ & - \\
\hline+ & L. mesenteroides ssp. & $\mathrm{ClO}_{2}$ & $1.5 \times 10^{6}$ & 0 & 99.9 \\
\hline+ & S. lentus & Control & $1.5 \times 10^{5}$ & Uncountable $^{* *}$ & - \\
\hline+ & S. lentus & $\mathrm{ClO}_{2}$ & $1.5 \times 10^{5}$ & 9 & 99.9 \\
\hline- & A. lwoffii & Control & $1.5 \times 10^{6}$ & Uncountable $^{* *}$ & - \\
\hline- & A. lwoffii & $\mathrm{ClO}_{2}$ & $1.5 \times 10^{6}$ & 0 & 99.9 \\
\hline- & A. salmonicida & Control & $1.5 \times 10^{5}$ & 330 & - \\
\hline- & A. salmonicida & $\mathrm{ClO}_{2}$ & $1.5 \times 10^{5}$ & 1 & 99.9 \\
\hline- & B. melitensis & Control & $1.5 \times 10^{5}$ & 420 & - \\
\hline- & B. melitensis & $\mathrm{ClO}_{2}$ & $1.5 \times 10^{5}$ & 0 & 99.9 \\
\hline- & O. ureolytica & Control & $1.5 \times 10^{7}$ & Uncountable $^{* *}$ & - \\
\hline- & O. ureolytica & $\mathrm{ClO}_{2}$ & $1.5 \times 10^{7}$ & 0 & 99.9 \\
\hline
\end{tabular}

$* 100$ - (Numbers after $24 \mathrm{hr} /$ Initial numbers) $\times 100$

** Uncountable indicated bacterial colonies to not be easily counted due to very high numbers of their numbers 
A

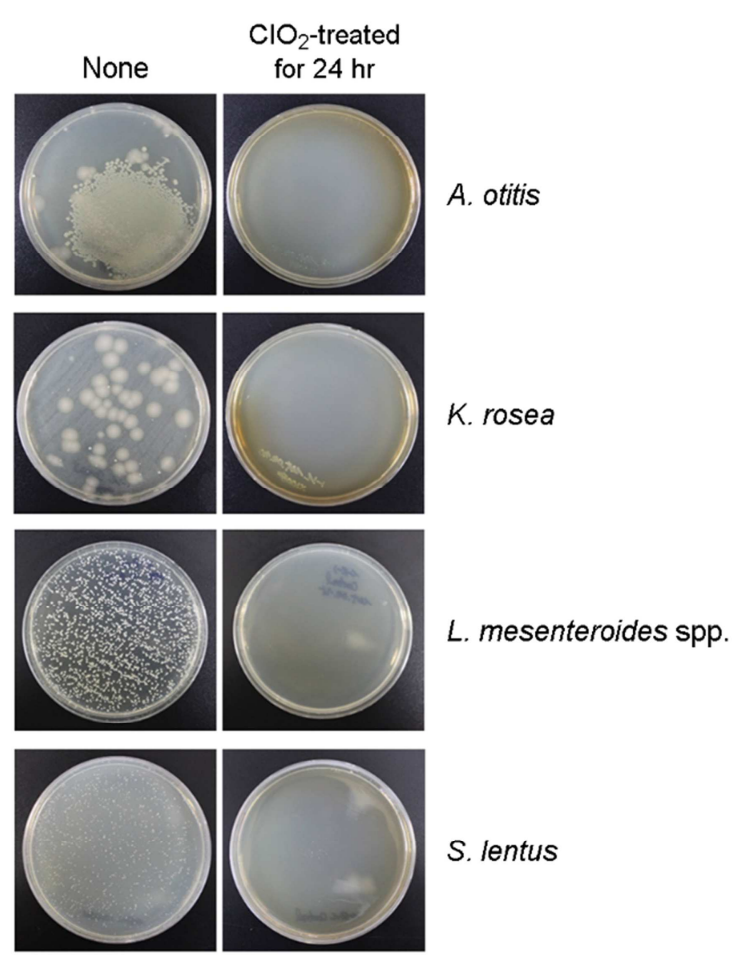

B

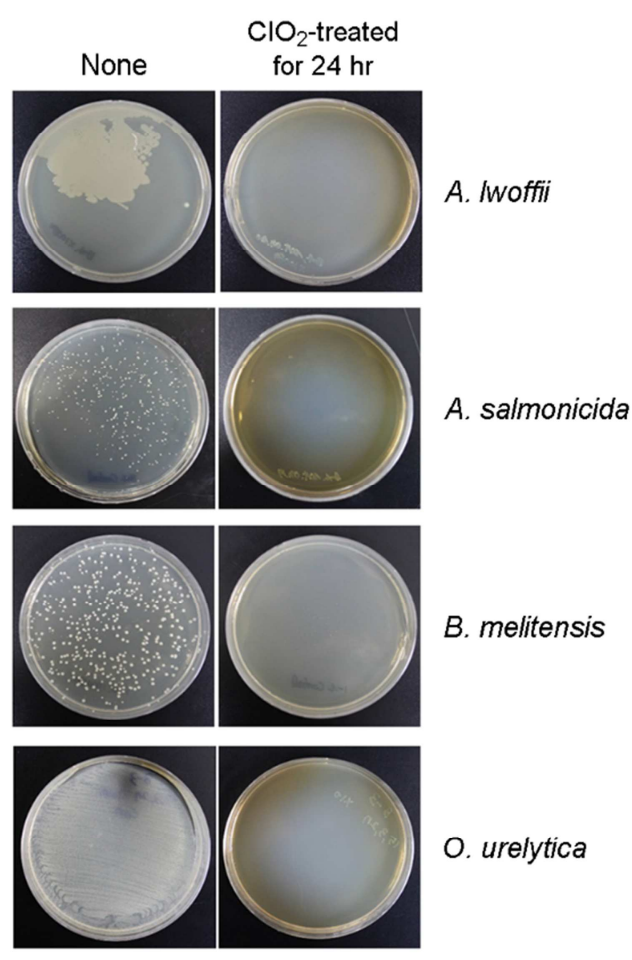

Fig. 1. Bacterial plates treated by chlorine dioxide gas for $\mathbf{2 4} \mathbf{~ h r}$. Four gram-positive (A) and four gram-negative bacteria (B) were applied.

The number of bacterial colonies formed after 24 hours with the plastic stick next to the bacterial plate was calculated (Table 1). The number and morphology of the bacterial colonies formed were visually analyzed, with less than 10 bacterial colonies estimated to be $99 \%$ inhibited and the 0.5 of McFaland turbidity used was sufficient to analyze inhibition by $\mathrm{ClO}_{2}$ gas. Fig. 1 showed bacterial colonies by the treatment of $\mathrm{ClO}_{2}$ gas. All bacteria could be easily counted, but $A$. otitis and A. lwoffii without $\mathrm{ClO}_{2}$ gas were not countable due to very dispersed colony types which were not affected for result analysis. A. otitis and $K$. rosea forming $1.5 \times 10^{8} \mathrm{CFU}$ were inhibited with $99 \%$ of no colony in treated with $\mathrm{ClO}_{2}$ gas. Taken together, FarmeTok releasing $\mathrm{ClO}_{2}$ gas was very effective to inhibit bacterial growth.

This study could give the information of uncommon clinical bacteria and effectiveness of chlorine dioxide-releasing plastic stick to prevent bacterial growth. Eight bacteria in this study were almost completely inhibited for growth by the $\mathrm{ClO}_{2}$ gas. $\mathrm{ClO}_{2}$ at concentration of 1.3 and $13 \mathrm{mg} / \mathrm{L}$ killed against these pathogens, e.g., Erwinia carotovora and
Ralstonia solancearum (Yao et al., 2010). In our study, the plastic stick of FarmeTok released $\mathrm{ClO}_{2}$ (13 ppmv/hr) gas and was sufficient to inhibit the bacterial growth.

Analysis of the efficiency and safety of chlorine dioxide showed that chlorine dioxide concentrations of 5 and 20 ppm, respectively, were sufficient to inhibit the growth of bacteria and fungi by $98.2 \%$. Some bacteria can be applied in specific condition and environments. Chlorine dioxide concentrations of $385 \mathrm{ppm}$ have been safely maintained in hospitals of large facilities (Lowe et al., 2013).

The inhibition mechanism of $\mathrm{ClO}_{2}$ is unclear, but the action of $\mathrm{ClO}_{2}$ is only known as inhibition. For porcine reproductive and respiratory syndrome virus (PRRSV), $\mathrm{ClO}_{2}$ could inhibit the first stage of viral life, which inhibited binding itself to cells where PRRSV was not internalized and released (Zhu et al., 2019).

The plastic stick releasing $\mathrm{ClO}_{2}(13 \mathrm{ppmv} / \mathrm{hr})$ gas was enough to inhibit the bacterial growth with $99 \%$. Although the pathogenicity of bacteria is not known to inhibit the growth of chlorine dioxide, the concentration of chlorine 
dioxide must be treated higher to inhibit the growth of methicillin-resistant S. aureus (MRSA) and K. pneumoniae, which are potent pathogenic. According to a research paper by different concentration of $\mathrm{ClO}_{2}$ (Hsu et al., 2016), after 40 weeks of $\mathrm{ClO}_{2}$ use by $0.3 \sim 0.5 \mathrm{mg} / \mathrm{L}$, the overall nonfermented gram negative bacillus colonies decreased significantly (hot water: $160 \pm 143$ vs $2 \pm 4$ cfu/mL).

Bacteria existing in the clinic such as this hospital will be used as a data to inhibit the growth of bacteria by using chlorine dioxide, and molecular biology analysis using the gene of bacteria is possible in the future rather than inhibiting the growth of bacteria itself.

\section{ACKNOWLEDGMENT}

Funding for this paper was provided by Namseoul university.

\section{CONFLICT OF INTEREST}

No potential conflict of interest relevant to this article was reported.

\section{REFERNCES}

Chung H, Kim H, Myeong D, Kim S, Choe NH. Effect of chlorine dioxide gas application to egg surface: microbial reduction effect, quality of eggs, and hatchability. Korean J Food Sci Anim Resour. 2018. 38: 487-497.

Fukayama MY, Tan H, Wheeler WB, Wei CI. Reactions of aqueous chlorine and chlorine dioxide with model food compounds. Environ Health Perspect. 1986. 69: 267-274.

Gómez-López VM, Rajkovic A, Ragaert P, Smigic N, Devlieghere F. Chlorine dioxide for minimally processed produce preservation: a review. Trends Food Sci Technol. 2009. 20: 17-26.

Hsu MS, Wu MY, Huang YT, Liao CH. Efficacy of chlorine dioxide disinfection to non-fermentative Gram-negative bacilli and non-tuberculous mycobacteria in a hospital water system. J Hosp Infect. 2016. 93: 22-28.

Jung KM, Lee GW, Cho MA, Song KJ, Jung SY. Effect of chlorine dioxide in reduction of harmful microbes on fermented hot pepper paste. Food Sci Biotechnol. 2019. In press.

Kim H, Yum B, Yoon SS, Song KJ, Kim JR, Myeong D, Chang B, Choe NH. Inactivation of Salmonella on eggshells by chlorine dioxide gas. Korean J Food Sci An. 2016. 36: 100-108.
Kim HG, Song KB. Combined treatment with low concentrations of aqueous and gaseous chlorine dioxide inactivates Escherichia coli O157:H7 and Salmonella typhimurium inoculated on paprika. J Microbiol Biotechnol. 2017. 27: 492-499.

Lim KB, Boey LP, Khatijah M. Gram's-stained microscopy in the etiological diagnosis of Malassezia (Pityrosporon) folliculitis. Arch Dermatol. 1988. 124: 492.

Lowe JJ, Gibbs SG, Iwen PC, Smith PW, Hewlett AL. Impact of chlorine dioxide gas sterilization on nosocomial organism viability in a hospital room. Int J Environ Res Public Health. 2013. 10: 2596-2605.

Lowe JJ, Gibbs SG, Iwen PC, Smith PW, Hewlett AL. Decontamination of a hospital room using gaseous chlorine dioxide: Bacillus anthracis, Francisella tularensis, and Yersinia pestis. J Occup Environ Hyg. 2013. 10: 533-539.

Moran T, Pace J, McDermott EE. Interaction of chlorine dioxide with flour: Certain chemical aspects. Nature. 1953. 171: 103 106.

Morino H, Fukuda T, Miura T, Lee C, Shibata T, Sanekata T. Inactivation of feline calicivirus, a norovirus surrogate, by chlorine dioxide gas. Biocontrol Sci. 2009. 14: 147-153.

Sanekata T, Fukuda F, Miura T, Morino H, Lee C, Maeda K, Araki K, Otake T, Kawahata T, Shibata T. Evaluation of the antiviral activity of chlorine dioxide and sodium hypochlorite against feline calicivirus, human influenza virus, measles virus, canine distemper virus, human herpesvirus, human adenovirus, canine adenovirus and canine parvovirus. Biocontrol Science. 2010. 15: 45-49.

Song KJ, Jung SY. Biocidal effects of chlorine dioxide on isolated and identified pathogens from nosocomial environmentbiochemical and technical convergence. J Digit Converg. 2017. 15: 339-344.

Song KJ, Jung SY. Growth inhibitory effects of chlorine dioxide on bacteria. Biomed Sci Lett. 2018. 24: 270-274.

Sy KV, McWatters KH, Beuchat LR. Efficacy of gaseous chlorine dioxide as a sanitizer for killing Salmonella, yeasts, and molds on blueberries, strawberries, and raspberries. J Food Prot. 2005. 68: 1165-1175.

Wang T, Wu J, Qi J, Hao L, Yi Y, Zhang Z. Kinetics of inactivation of Bacillus subtilis subsp. niger spores and Staphylococcus albus on paper by chlorine dioxide gas in an enclosed space. Appl Environ Microbiol. 2016. 82: 3061-3069.

Wu WC, Kim BC. Effect of a simple chlorine dioxide method for controlling five foodborne pathogens, yeasts and molds on blueberries. Food Microbiol. 2007. 24: 794-800. 
Xu F, Wang S, Xu J, Liu S, Li G. Effects of combined aqueous chlorine dioxide and UV-C on shelf-life quality of blueberries. Postharvest Biol Technol. 2016. 117: 125-131.

Yao KS, Hsieh YH, Chang YJ, Chang CY, Cheng TC, Liao HL. Inactivation effect of chlorine dioxide on phytophathogenic bacteria in irrigatin water. J Environ Eng Management. 2010. 20: 157-160.

Zhu Z, Guo Y, Yu P, Wang X, Zhang X, Dong W, Liu X, Guo C. Chlorine dioxide inhibits the replication of porcine reproductive and respiratory syndrome virus by blocking viral attachment. Infect Genet Evol. 2019. 67: 78-87.

https://doi.org/10.15616/BSL.2019.25.4.431

Cite this article as: Jung SY. Inhibition of Clinical Nosocomial Bacteria by Chlorine Dioxide. Biomedical Science Letters. 2019. 25: 431-435. 